\title{
Orbital Sarcoma Pathologic Regional Lymph Nodes TNM Finding v8
}

National Cancer Institute

\section{Source}

National Cancer Institute. Orbital Sarcoma Pathologic Regional Lymph Nodes TNM

Finding v8. NCI Thesaurus. Code C140847.

A pathologic finding about one or more characteristics of orbital sarcoma, following the rules of the TNM AJCC V8 classification system as they pertain to staging of regional lymph nodes. 